\title{
Chapter 8 \\ Post-disaster Development Dilemmas: Advancing Landscapes of Social Justice in a Neoliberal Post-disaster Landscape
}

\author{
Anna Livia Brand and Vern Baxter
}

\subsection{Introduction}

Disasters like Hurricane Katrina generate deep debate about human vulnerability and the viability of built environments. Fundamental questions raised in the aftermath of disaster include how could they live there, why would they live there? It is difficult for those facing the impacts of disaster to field unwelcome questions about connections to home and place. We all have connections to the places we live that go beyond rational measurement and plumb the depths of emotion. Well-understood psychological reasons draw people home to an imaginary state that existed before lifeworlds were rendered unrecognizable by disaster (Burley 2010). But there is no going back after Katrina. The storm and ensuing levee failures left an enduring mark on the city. It displaced over a million people, devastated the Gulf Coast, and claimed the lives of over 1000 Louisiana residents (Plyer 2016).

While there is no going back, the road forward is unclear. Post-disaster planning is often framed as a moment from which a new future landscape might be imagined. The wake of disaster invites imaginings of more socially just settlement patterns and inspires radical alternatives to what was there before. Myriad individuals and groups invested time and energy shaping a positive recovery imaginary in New Orleans, from the scale of neighborhood meetings patched together in churches and schools, homes, and front porches to the scale of city-wide meetings that spanned nearly 10 years after Katrina.

\footnotetext{
A. L. Brand $(\bowtie)$

Department of Landscape Architecture \& Environmental Planning,

University of California Berkeley, Berkeley, CA, USA

e-mail: annalivia@berkeley.edu

V. Baxter

Department of Sociology, University of New Orleans, New Orleans, LA, USA

e-mail:vbaxter@uno.edu
} 
For many, this future landscape was imagined as resilient, green and sustainable, socially just and equal. Yet policy makers and urban designers who raised questions about how, why, and where resettlement should take place in the wake of Katrina often excluded the deeply unequal and settled patterns of a racial state, geographies developed, and resisted over different racial formations and political economies of urban development across the city's history. Further, they often failed to imagine how processes like advanced capitalism and racism work geographically in the twenty-first century or might work in a disaster context. Therefore, outside of specific and even narrow instances, the larger post-disaster story fails to meet these hopes, despite moments where more racially and socially just solutions prevail.

Indeed, many questions remain about what the future might bring and what shape vulnerability might take. Hurricane Katrina and more recent environmental disasters (e.g., Hurricanes Harvey, Irma, and Maria) transpired under the hegemonic reign of a neoliberal political economy. Neoliberal doctrine above all advances individual freedoms and social well-being within an institutional framework defined by strong private property rights and free markets, where the state generally assists and facilitates business and private development goals (Harvey 2005, p. 2). A tilt toward private sector solutions to planning and urban development problems pre-dates Katrina and aptly characterizes recovery and rebuilding efforts over the past dozen years. Contemporary human, social, racial, and environmental justice claims are made on the state within a dominant neoliberal paradigm, whose colorblindness (Omi and Winant 2014) makes it difficult to advance the type of equity work needed to address the deeply racialized disparities that characterized the city before the storm. Perhaps more concerning, the social justice limitations of neoliberalism make it imperative that we not only articulate its operation as a foundation for disaster response and future planning but we also unsettle its often unquestioned position as the dominant economic paradigm of our generation.

Deep racial and social inequality and concurrent patterns of geographic expression are not new to New Orleans, but the moment of Katrina and ensuing years of redevelopment reflect compounding development dilemmas that make it hard to advance social justice claims. The larger political economy within which a disaster unfolds helps shape possible and probable responses. Disasters also unfold on racial landscapes that unequally affect people of color. Finally, a deeper environmental development history contextualizes both disaster and rebuilding. Separately, these development dilemmas are at odds with goals of a more socially, racially, economically, and environmentally just landscape. Together, they solidify a rebuilding based on elitism and reproduction of privilege carried over from long historical trajectories of racism, political economy, and a skewed environmental landscape on which claims for social justice are lodged.

This chapter explores these interrelated and compounding development dilemmas and argues that these dilemmas, both on their own and together, impede the advance of social justice as a normative claim on urban planning and the state. The three development logics that dominate post-Katrina New Orleans-neoliberalism, racialization, and land/environmental development - set the stage for how planners imagine and rationalize the future trajectory of the city. Although post-Katrina 
development was also shaped by resistance to these frameworks, we explore how social justice claims were fundamentally limited by these dominant logics.

In the following sections, we explore how particular strategies of a neoliberal political economy and neoliberal ideology shaped planning and recovery in New Orleans after Katrina. Next, we argue that racialized landscapes and the long history of race as development logic have also shaped planning and reenvisioning the city's future. We then turn to a discussion of how the longer history of unequal environmental vulnerability presents specific post-disaster development dilemmas. We then discuss how these development dilemmas compound one another to shape normative ideas of state action and equity in a post-disaster moment and argue that to envision a more just landscape requires further articulation of how the three dilemmas work in concert to reproduce inequality.

\subsection{Neoliberal Disaster Landscapes}

More attention is warranted to the ways neoliberal ideologies prevailed in the urban planning process before and after disaster and, therefore, to one of the main forums through which recovery ideas, representations, and development agendas are shaped. Raising questions about how neoliberal ideologies work in recovery planning requires that we think through ideological shifts at work in late capitalism and how these shifts emerge in the disciplines and logics of urban development and planning. Understanding the embeddedness of neoliberal ideologies like personal responsibility, entrepreneurialism, and primacy of private over public solutions to collective problems, as plausible responses to disaster and post-disaster urban planning, requires that we resituate the moment of Katrina as it unfolded from a much longer trajectory of unequal development.

The neoliberal moment in post-disaster New Orleans was foreshadowed by an earlier tilt toward private sector solutions to planning and urban development problems that created a context for disaster capitalism and rebuilding after the storm (Klein 2007). Manufacturing decline and the oil crisis of the late 1980s brought a deep recession, high unemployment, and incarceration rates of mostly black residents that reached the highest in the world, while a narrative of individual failure accompanied an attack on public housing as the site of social problems and urban decline. The oil bust, coupled with the larger retrenchment of the social welfare state (Peck and Tickell 2002), further solidified an urban geography of white population loss, poorly performing and racially segregated public schools, and segregated and deteriorating housing stock (Lewis 2003). While certainly these shifts were resisted at every turn (Woods 2017), racial geographies of the city calcified prior to Katrina through a complex renaissance of downtown development and abandonment (Campanella 2006) that had gentrified much of the historic higher ground. By the 1990s, advance of the city's tourist economy was marked by a hotel boom downtown and increased gentrification on high ground (Campanella 2006). 
The city's long stigmatized and ignored public housing developments invited market-based alternatives and public-private partnerships, both before and after the storm, to replace publicly funded housing. Much like other cities, the federal Department of Housing and Urban Development (HUD) failed to adequately maintain public housing projects in New Orleans as part of a decade-old strategy to engender crisis and justify demolition of public housing. Since the 1980s, the federal government supported solutions to low-income housing problems with a series of programs (e.g., Business Improvement Districts, Community Development Block Grants, New Market Tax Credits, Low Income Housing Tax Credits (LIHTC)) committed to private initiatives, while moral entrepreneurs trumpeted individual solutions to problems of the poor (Peck 2006; Wacquant 2010). An ethic of selfsufficiency and entrepreneurialism accompanied creation, in 1974, of the Section 8 housing voucher program and the use of LIHTC and Hope VI programs to support demolition of public housing and subsidies for low-income homebuilders instead of low-income housing residents (Hackworth 2007, pp. 47-8). In New Orleans, the St. Thomas housing project met the wrecking ball in 2002 to clear land in the Lower Garden District for gentrification (Arena 2012). Tax Incremental Financing (TIF) helped fund the new mixed-income River Gardens Apartments and Walmart store at the former St. Thomas site as a blueprint for the demolition of public housing after the storm (See Fig. 8.1).

Like other U.S. cities, a retrenchment of social welfare provisions and publicly funded health care in New Orleans before Katrina accompanied growth of a disadvantaged population reliant on non-living wage jobs in an increasingly touristdependent city (Gotham 2007). Additionally, increased privatization of public facilities and institutional infrastructure preceded Katrina, as did other forms of devaluation and destruction (Brenner and Theodore 2002). The transfer to the state's general fund for 10 years before the storm of federal money (under Disproportionate Share program) appropriated to maintain and upgrade Charity Hospital is an example of degrading public facilities in preparation for privatization and the roll out of gentrification (Ott 2012). Plans to abandon Charity Hospital and develop a biomedical district in the Mid-City neighborhood adjacent to downtown were proposed prior to Katrina. Like public housing, maintenance on the hospital was deferred, which helped create a crisis in public sector health care. Minimal flooding during Katrina enabled Louisiana Governor Kathleen Blanco to close the hospital and appoint Louisiana State University to oversee it. Blanco's successor, Governor Bobby Jindal, hired private contractors in 2013 to manage the rest of the state's public hospitals, while the federal government agreed to spend $\$ 625$ million for a new Veteran's Administration Hospital to anchor gentrification and poverty removal across the Mid-City neighborhood (see Fig. 8.1).

Privatization also impacted the City's public-school system prior to Katrina. Just before the storm, poor overall performance on standardized tests by students in the New Orleans public school system prompted a shift in control of the system from the local School Board to a state contractor, the private accounting firm of Alvarez 


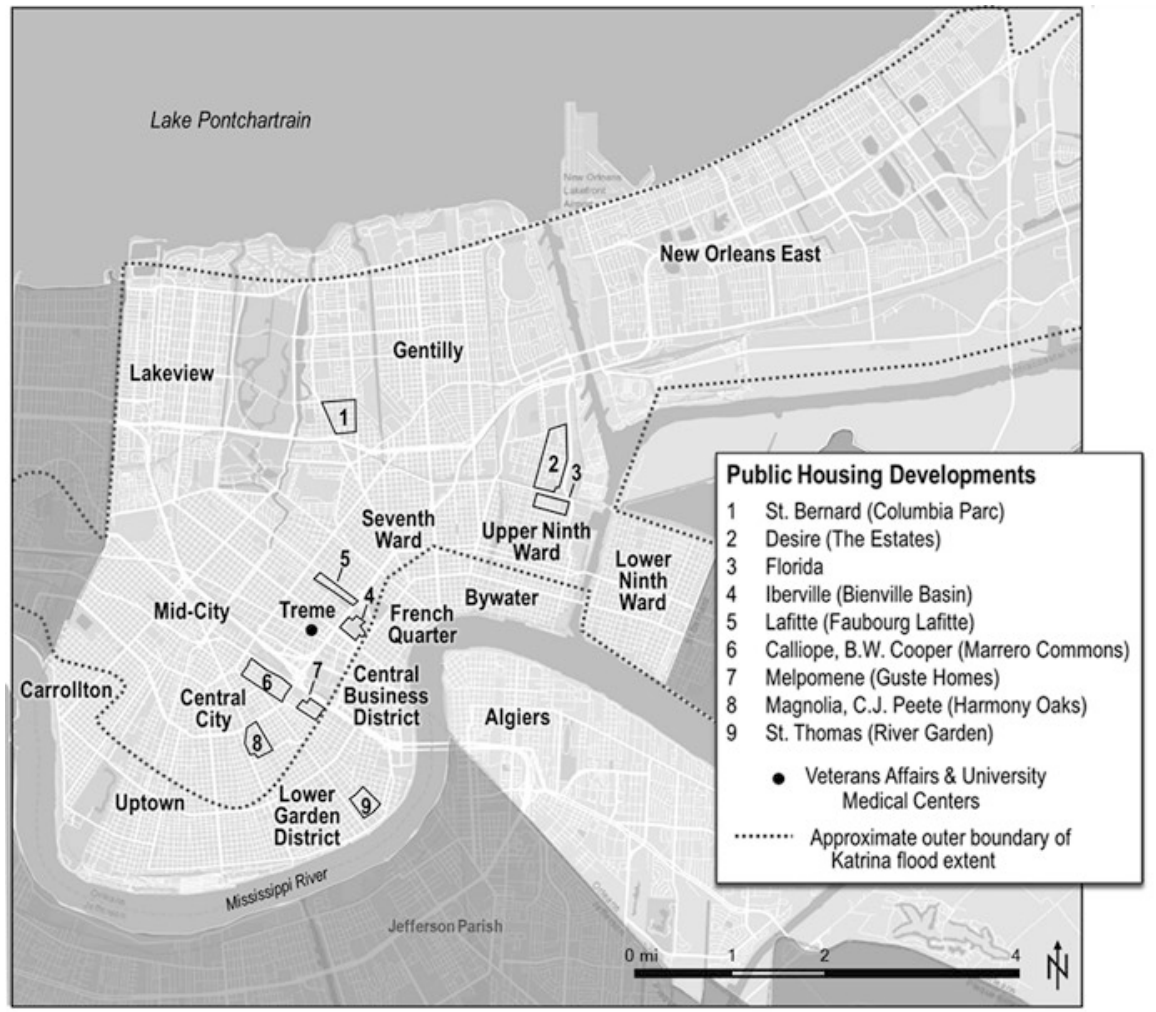

Fig. 8.1 Map of Orleans Parish, LA, showing neighborhoods and the locations of major public housing developments as they were before Hurricane Katrina. (Data retrieved from City Planning Commission of New Orleans and Google Maps. Base map courtesy of Esri, DeLorme, HERE, MapmyIndia, ( O OpenStreetMap contributors, \& the GIS community)

and Marcel. Days after the storm shuttered the city's schools, 7500 public school teachers were laid off, their unions broken, and their schools reopened as charter schools or as private schools funded by state vouchers (Brown 2015; Akers 2012). More flexible employment conditions now prevail and tenure protection was removed for teachers in a decidedly neoliberal transformation of New Orleans public education.

The advance of private profit and individual solutions to collective problems in the years prior to Katrina effectively calcified deep social, economic, and environmental inequalities and normalized what would be a flood of neoliberal policy measures advanced in the wake of Katrina. While racial and environmental equity and sustainability were fought for locally, particularly by African-American residents in the years preceding Katrina, "the disaster before the disaster" laid the groundwork for what would unfold later. 


\subsubsection{Neoliberal Ideology and Urban Planning in Post-Katrina New Orleans}

The slow entrenchment of multiple crises prior to Katrina was coupled after the storm with actual destruction. The moment of Katrina was a window, or a "moment of creation" (Brenner and Theodore 2002) within which reconfiguring of the city's land-use patterns became possible. This formerly declining city was reimagined as a city with a resilient future, but this future was promised by a market-based logic that guided public housing reform, public education, environmental resilience, racial integration, and gentrification. The localization of larger neoliberal spatial and privatization paradigms that took root in New Orleans in the years following the storm reshaped the city through multiple sectors and mechanisms, including urban planning (Brenner and Theodore 2002; Johnson 2011).

As Peck (2006) notes, much of the post-Katrina moment was shaped by the slow pace of immediate recovery efforts and by narratives formed about the city and its residents. Despite adherence to color-blind ideology, post-Katrina narratives, in both the media and across conservative think tanks, were dominated by depictions of the black, urban poor as "savages who resorted to murder, rape, and destruction during a time of crisis" (Peck 2006; Whitehall and Johnson 2011, p. 60). This depiction extended larger narratives about New Orleans as a crime-ridden and immoral city in decline, but it also played out an individualized racist depiction of the urban poor and working-class residents of many neighborhoods. These conservative narratives defined the city's problems (and its residents) and, from this perception of delinquency, crime, welfare-dependency, and government corruption, proposed policy orientations for rebuilding the city that centered the private market, limited federal initiative, and demanded individual accountability in exchange for government support.

The advance of a "common sense" neoliberalism at the local level informed redevelopment policies at all scales and influenced which neighborhoods were deserving of recovery efforts and dollars (Johnson 2011). In the months following the storm, then New Orleans Mayor Ray Nagin initiated a planning process when he created the Bring New Orleans Back Commission (BNOB 2006). The BNOB urban planning committee promoted a limited return of residents to the city and proposed a reduced geographic footprint at the same time that they recommended deployment of resources to areas and residents least affected by flooding rather than to areas and people hardest hit by the storm (Brand 2007; BNOB 2006). Although the Mayor backed away from his own committee's recommendations, the lingering focus on neighborhood scale redevelopment occupied a central place in subsequent planning efforts, as did unresolved concern about who could return home after the storm. Of course, a lack of citizen participation in this planning effort and its limited analytical rigor limited the plan's capacity to address the uneven racial geography of the city, not to mention the city's environmental vulnerability. However, subtle support for removal of unwanted residents (areas proposed for return to green space were 
racially mixed or predominantly black) was rationalized as a more suitable and sustainable development plan. The BNOB logic of prioritizing rebuilding based on depth of flooding and likelihood of residents to return reveals how the neoliberal discourse of individual market power can extend to redevelopment plans that prioritize the upper middle class and their right to the city over that of poor residents of color (see also Chap. 9 of this volume).

Indeed, residents of many neighborhoods were told that they had to prove their viability to rebuild and were forced to compete for public resources such as public schools and street repairs. Each of the city's subsequent major planning efforts promoted individualization of neighborhood recovery and reinforced market-driven redevelopment agendas. Much of the post-disaster planning and development process proceeded with a competitive approach that pitted neighborhood against neighborhood, combined with targeted recovery zones meant to incentivize private investment. Community-level planning was one way that residents engaged this dilemma and resisted limitations of a neoliberal recovery paradigm (Brand 2007). However, while neighborhood-level input and participation were critical to the city's master planning and zoning efforts, what remains missing from city-led planning is a deeper consideration of the distributional consequences of recovery spending in each neighborhood and how residents' ideas about equity reflected their various privileges (Brand 2015; Reardon et al. 2009).

\subsubsection{Post-Katrina Development Outcomes}

Policies and ideas associated with neoliberal urban reform and a new form of uneven development define redevelopment strategies and landscapes after Katrina. A further focus on entrepreneurism in the post-disaster city reinforced individual responsibility for recovery while also supporting a free-market redevelopment landscape. In addition to a full-scale restructuring of public education and public/affordable housing, transformations of the city also include massive land clearance, the redevelopment of a Bio-Medical district in Mid-City, and a reworked racial and economic landscape that privileges gentrification, expansion of racial privilege, and new forms of exclusion and abandonment.

Thousands of public housing residents were displaced without access to their belongings when slightly flooded and historically undermaintained public housing projects were closed after Katrina. The revalorization of public housing sites in post-Katrina New Orleans relied not only on discursive strategies that devalued and stigmatized these properties but also on neoliberal urban development solutions designed to privatize public property (Weber 2002). The federal department of Housing and Urban Development (HUD) and local Housing Authority of New Orleans (HANO) announced plans in June, 2006, to demolish the "Big Four" housing developments (C.J. Peete, Lafitte, St. Bernard, B.W. Cooper-see Fig. 8.1), home to 4500 people before the storm (Tulane School of Architecture 2007). Local 
residents and preservation activists struggled mightily to convince authorities to repair and reopen public housing, but in a dramatic 7-0 vote on December 1, 2007, the New Orleans City Council endorsed demolition.

Public housing projects demolished after the storm were replaced by an expansion of Section 8 low-income housing vouchers and mixed-income developments that featured a combination of market rate, subsidized, and a reduced number of public housing units. A federal Gulf Opportunity Zone (GoZone) designation enabled allocation of New Market Tax Credits (NMTC) and other public funds to private firms like Capital One, Enhanced Community Development, Whitney New Markets Fund, Crescent Growth Capital, and other "tax credit equity investors" that could partner with private developers like HRI, Columbia Residential (St. Bernard Development), Providence Community Housing, L + M Development Partners (Lafitte Development), and others to build mixed-income developments where most units command market rents (Novogradac 2015). Before the storm, the St. Bernard Public Housing Development contained 1464 public units; its replacement, Columbia Parc, has 221. C.J. Peete public housing contained 1403 public units; its replacement, Harmony Oaks, has 198. Guste public housing contained 993 public units; its replacement has 577 (Webster 2016a). The over 3300 fewer families now living in public housing were low-income, mostly black residents displaced by neoliberal post-Katrina housing policies to make way for gentrification of large swaths of Central and Mid-City, Treme, and the Lower Garden District (see Fig. 8.1).

The same publicly subsidized private companies that built mixed-income housing on sites made vacant after demolition of public housing often built off-site private housing near the vacated sites (e.g., Enterprise Community Partners and L + M Development built near former Lafitte public housing development (see Fig. 8.1)). These companies also did commercial developments nearby (e.g., L + M developed Whole Foods in Mid-City) to claim increased rents available from poverty removal and gentrification. A prominent example of publicly subsidized private commercial and community service property development is Crescent Growth Capital, which lined up NMTC financing for New Orleans Culinary Hospitality, Ursuline Academy, NOMMA School, NOCCA, Myrtle Banks, Carver Theater, Joy Theater, St. Margaret's Daughters Home, Belleville Assisted Living, New Orleans Healing Center, Transportation Consultants at Port of New Orleans, and others-all part of the neoliberal strategy of using the tax code rather than government grants as a market-driven approach to incentivize private sector investment in low-income communities (Crescent Growth Capital 2018).

The Section 8 voucher program was expanded after Katrina to replace public housing and meet housing needs of other low-income residents. In 2005, Housing Authority of New Orleans (HANO) served 14,129 families-8981 received vouchers and 5148 lived in public housing. In 2016, HANO served 19,175 families and only 1820 , or $9 \%$, lived in public housing (Webster 2016a). Higher rents and a shortage of rental housing meant more residents needed housing assistance after the storm. The Section 8 waitlist currently stands at 20,000 and is closed to additional residents in need of housing assistance (HANO 2019). Available federal assistance under the Section 8 program pays landlords favorable rents and places additional 
cost burdens on poor residents. Section 8 housing costs are higher than public housing costs because residents must pay deposits, utilities, and up to $30 \%$ of their income in rent (Webster 2016a). Most Section 8 vouchers pay for housing in low-income black neighborhoods, many in the large residential area called New Orleans East, and most are located away from higher-ground neighborhoods along the river. One report concluded that $82 \%$ of landlords, most in more affluent neighborhoods, refused to accept vouchers or placed unreasonable demands on tenants, which suggests that the Section 8 program reinforced racial residential segregation after the storm (Webster 2016a).

While both the closure of public housing and precariousness of public education and public transit make it harder for working-class or poor families to thrive in the city, these moves are rationalized by past failures of the state and the continuing criminalization of the poor. As expected, neoliberal urbanism is reflected in a new urban form that, as discussed above, includes large-scale redevelopment, new urban housing markets, and an intensification of gentrification (Barrios 2010; Brenner and Theodore 2002). New forms of gentrification and uneven development intersect with the appropriation of black sociospatial culture and environmental sustainability. It is important to point out here that the frontiers of development in post-Katrina New Orleans have been unevenly distributed across neighborhoods. Affluent, white, but heavily flooded Lakeview received instant endorsement for rebuilding after the storm while post-Katrina environmentalism prompted near abandonment of black neighborhoods in New Orleans East and the Lower Ninth Ward. Gentrification and attraction of new white residents to "authentic" black areas like Treme were accompanied by near abandonment by publicly organized rebuilding efforts of other predominantly black, less gentrifiable neighborhoods (Brand and Bailey 2017). Cultural gentrification and tourism-based promotion of black culture in the historic Treme neighborhood may bring benefits to individual residents, but it simultaneously displaces producers of local culture (Kelley 2003). We move next to locate the neoliberal transformation of post-Katrina New Orleans within the re-racialization of the city's inhabitants and landscapes.

\subsection{Racial Landscapes, Racial Processes, and Racialization}

It is unquestionable that pre-Katrina New Orleans was not a socially just or equal landscape. This does not imply that residents in the city's most neglected neighborhoods did not have strong connections to place or that their sociocultural and spatial practices did not signify alternative interpretations and imaginations about their built and social landscapes (Brand 2018). It does mean that residents long suffered from failing public schools, poor access to living wage employment opportunities, and urban development histories that left many poorer and predominantly black urban areas particularly vulnerable to flooding, environmental/developmental racism, and disinvestment. Although the emergent city can be understood in a neoliberal framework, the cementing of market logic and individualized solutions to 
collective problems must also be framed both as an extension of deeper historical geographies and as (re)racialization of the city's landscapes. The landscape within which Katrina unfolded was unequal by nearly every metric that urban planners use to measure a place and its people, ${ }^{1}$ presenting a post-disaster development dilemma that, while not new or even unique in the larger American context, reflects the depth and expansiveness of racial/spatial formation. The sheer historical depth of racial geographic expression in the United States, now exacerbated by disaster and a political economy that limits claims based on racism, presents specific development dilemmas for those wishing to attend to racial, spatial, and socioeconomic justice.

In this section, we rely on a conceptualization of racial processes as inherently spatial (McKittrick 2006). The spatial formation of race can be tracked and understood just as racial processes can be tracked and understood through their ideological and practical shifts over time (Omi and Winant 2014). An inquiry into the racial landscapes of New Orleans requires resituating our analytical/temporal framework to grasp the rise of neoliberal space making and the "as is" essentialism and reduction of black lives that informed post-Katrina narratives (McKittrick and Woods 2007, p. 6). The time and space of race at the moment of Katrina are therefore complexly arranged geospecific contexts represented not by their settled contours but by their shifting enactments of ongoing racial processes. The New Orleans racial landscape, like that of most Southern American cities, is rooted in the formation of the city and its longer history of colonization, slavery, and post-emancipation segregation. Patterns set forth by both slavery and freedom are set deeply into neighborhoods like Central City, the Lower Ninth Ward, Treme, and New Orleans East, where the city's majority black population lives.

\subsubsection{An Historically Racialized Landscape}

The landscape of New Orleans is thoroughly racialized. White settlement of the historic high ground between the Mississippi River and Lake Pontchartrain required removal of indigenous Native Americans and forced migration of enslaved Africans into the city. Enslaved Africans were bound both to the land and to their masters in a primitive state of incarceration. This was a racial dictatorship protected by religious ideology that prevailed for more than 250 years (Omi and Winant 1994, p. 65). The toil of enslaved bodies transformed the landscape and embodied wealth that engendered profit, status, and credit for the enslaver. Antebellum historians largely

\footnotetext{
${ }^{1}$ Part of the dilemma for urban planners are the metrics used to measure place and people. As McKittrick and Woods (2007) argue, while identifying and mapping racial inequalities is critical to the task of naming racism, this effort, when not accompanied by efforts to see and understand how black geographies are made through struggle and resistance (6), reifies and naturalizes racialized inequality and uneven racial geographies. While a fuller discussion of this dilemma is out of the scope of this chapter, it should be noted that many of the measurements served up as evidence of the city's failures were used to further neoconservative and neoliberal redevelopment agendas (see Peck 2006, etc.) in the wake of Katrina.
} 
recognize the combination of enslaved labor and collateral as fundamental to development not only of the landscape of New Orleans but of global industrial capitalism and the industrial revolution (Baptist 2014; Du Bois 1962 [1935]; Johnson 2013).

Enslaved Africans in antebellum New Orleans were concentrated uptown along the Mississippi River near white plantation owners, while free people of color mostly lived downriver and "back of town" in Treme and the Seventh Ward (Morse 2008; see Fig. 8.1). Renegade enslaved Africans, Native Americans, and other outcasts occupied the back swamps of the city. After reconstruction, scientific theories of racial inequality legitimated race-based segregation and most black people were segregated into squalid dwellings in low-value, flood-prone swampland like Gert Town and Broadmoor (see Fig. 8.1).

The invention of the wood screw pump in 1917 permitted drainage of the back swamps of Mid-City and the Lakefront area which prompted white flight to these early suburbs and reinforced the location of whites in better drained parts of the city (Colten 2005, p. 77; Spain 1979). While shaped by the rationality of progressive era approaches to public works, and public health concerns of planners, development of the city's drainage and sewer system during the Jim Crow era of racism meant that newly expanded urban "territories" were racially and economically segregated as they emerged from the swamps (Colten 2002, p. 239, 2005; Lewis 2003). Black areas were cordoned off by commercial and industrial corridors (e.g., Dryades Market) laid out in the first Comprehensive Zoning Ordinance of 1929 and by restrictive covenants that blocked blacks from white neighborhoods (Hastings 2004, p. 300, 326; Morse 2008). Chronic housing shortages plagued the black community after World War II when passage of the Federal Housing Act of 1949 extended the federally funded public housing program to construct segregated housing in cities across the country (Von Hoffman 2000). The location of federally funded housing developments built for blacks only in New Orleans in the 1940s and 1950s further concentrated the black population in the Second (B.W. Cooper/Calliope), Seventh (St. Bernard), Ninth (Desire), and Eleventh (Magnolia) Wards, creating a black residential belt off the river, much of which was formerly back swamp (Spain 1979).

Civil rights struggles and the emergence of a more democratic racial ideology failed to challenge the racialization of space in New Orleans. The official collapse of the separate but equal doctrine that justified Jim Crow segregation until the 1954 Brown v. Board of Education decision of the US Supreme Court coincided with construction of separate but equal suburban housing in 1955 at Pontchartrain Parkwalled off from surrounding white suburbs by canals and a railroad line, one road in and one road out (Baxter and Casati 2019). Segregation was further reinforced by construction of the Desire housing project in 1956 in the Upper Ninth Ward on low ground next to the Industrial Canal. The Ninth Ward served generally as a landscape for blacks displaced from their homes by construction of Armstrong Park, Union Passenger Terminal, City Hall, the Superdome, and Interstate 10 (Spain 1979; Crutcher Jr 2010). Initially supported by construction of the I-10 expressway along Claiborne Avenue (through the city's historically black Treme and seventh Wards), the construction of lower-income subdivisions and later white flight from formerly integrated neighborhoods during the oil crash and recession of the late 1980s made 
New Orleans East yet another black area located on "reclaimed" swamp land.

As previously noted, the geography within which Katrina unfolded was critically and indelibly marked by generations of urban development paradigms that were themselves inherently raced. The deeper history was of course always marked by struggle and the resistant spatial ontologies of communities of color, as Woods (2017) argues in his historical analysis of the pre-Katrina city. Yet, while a nascent neoliberal bent would harden through post-Katrina development, the colorblindness of neoliberalism would recalibrate the city's racial geographies through new modes of abandonment, asset-stripping, and gentrification (Woods 2017).

\subsubsection{Newly Racialized Landscapes}

Post-Katrina racialization takes place through multiple sectors: including tourism, the demolition of public housing, public education reform, gentrification, public transportation investments, and tourist-centered redevelopment. It also included hyperdevelopment and abandonment. This framework accounts for abandonment of the Lower Ninth Ward and much of New Orleans East, as well as for unprecedented levels of development and gentrification pressure in Treme, Mid-City, and highground neighborhoods along the river such as Bywater (Brand and Bailey 2017). Population shifts after Katrina are one indication of changing racial demographics. Between 2000 and 2016, the city lost over 95,000 black residents (U.S. Census 2000; 2010; U.S. American Community Survey 2016). Geographically, this loss is represented in black population decline in areas along the river and adjacent to downtown, particularly in high-ground neighborhoods like Bywater, the Marigny, Central Business District (CBD), and Lower Garden District (see Fig. 8.1).

Pre-Katrina land tenure and valuation trends recalibrated in many ways after Katrina. Several majority black housing projects were constructed on lower ground and anchored low-income black neighborhoods with low rents and low house values. The historical context of racialized neighborhoods is that blacks are less able than whites to obtain home mortgages either because they are excluded from housing markets or because they have, on average, much less money and less stable jobs than whites. That means black residents are more likely than white residents to rent as opposed to purchase a home. This left many black residents without a real voice in a recovery process after Katrina that was heavily tilted toward homeowners (Reed 2006; Morse 2008). Residents of poorer black neighborhoods (typically on lower ground) with more renters and lower house values were also considered less likely to return and rebuild after the storm than residents of wealthier white neighborhoods like Lakeview.

Land formerly occupied by public housing sites (St. Bernard, Iberville, Lafitte, St. Thomas), and by majority black residents, was coveted by developers and potential white residents because of its elevation and proximity to employment downtown. Indeed, the advance of mixed-income and market-rate approaches to redeveloping sites on historic and largely unflooded high ground significantly 
reduced black population. The storm allowed closing of this racially based rent gap and displacement of low-income black renters so gentrification could proceed, leaving "symbolic" numbers of black residents within the subsidized portion of new federally backed housing built in the wake of the storm.

Beyond renters, black homeowners were also short-changed as the Road Home program funded by HUD and the State of Louisiana to help homeowners not covered by the National Flood Insurance Program initially allocated grants based on the value of the house pre-Katrina rather than the cost of repairs to the house after the storm. That meant houses in Lakeview neighborhoods occupied by whites received much larger average rebuilding grants than houses in Gentilly and the Lower Ninth Ward occupied by blacks. This inequity was remedied by a later court case, but most black homeowners were never made whole given that the court decision was not retroactive for property owners who had already made claims.

Asset-stripping describes well the allocation of disaster funding after the storm (Woods 2017). The statute that authorized Community Development Block Grant (CDBG) funding for New Orleans originally required that 70 percent of all money be awarded to support persons of low to moderate income. The State of Louisiana obtained waivers from the federal government after Katrina and ended up granting only 34 percent of CDBG money to low- and moderate-income residents. Homeowners received 79 percent of the grant money while the 34 percent of residents identified as renters received only 20 percent of CDBG grant money (Morse 2008). CDBG funding was also used for projects such as the Lafitte Greenway and Crescent Park, supporting public space expansion in areas experiencing rapid land revaluation and green gentrification (Anguelovski, Connolly and Brand 2018). This exemplifies the compounding dilemma of market-based economic logic rooted in deeply racialized systems of spatial inequality.

Snapshots of reinvigorated racial inequality include the continued lack of a grocery store in the Lower Ninth Ward and lack of sustained redevelopment in New Orleans East. Both areas continue to exhibit the slowest rate of return after Katrina. The slow rates of return reveal the intertwined workings of racialized capitalism and development given the direct prohibitions on residents' return (particularly in the Lower Ninth Ward) but also the ways that racial geographies unfold along with new contexts of geographical abandonment, continued inequalities in access to resources, and market-based development ideologies that typically avoid lower-income communities of color.

Racial processes are also evident in the return of middle-class and white elites to the city through production of luxury housing stock on high ground near the river and in the revaluation of property in the CBD and Mid-City neighborhoods. It takes place through the reconfiguration and aspatial reorganization of public education delivered by charter schools, the focus on tourist-oriented transit development (Lowe et al. 2018), and further calcification of the city's tourist economy (Gotham 2007). It also takes place through the abandonment of a dedicated public hospital for the city's poor and low-income residents as disaster recovery money was spent in the biomedical district to facilitate economic redevelopment in Mid-City. 
A final point on racial landscapes that is underexamined in urban planning, including post-disaster planning, is the continued emphasis on economic opportunity, which obfuscates how white supremacism and privilege operate spatially. Many planning scholars advance platforms for racial equity and highlight claims on the state and on our collective urban imaginary for more racially just landscapes, and these views go above and beyond economic opportunity (Bates et al. 2018). Our point is that more work is needed in urban planning on how racial geographic structuring and white supremacism work in and through our discipline.

\subsubsection{Racialized Space as Development Dilemma}

The endurance of the city's racialized geography poses specific development dilemmas often overlooked and ill-conceived in the realm of post-disaster urban planning. The seeming intractability of the city's unequal racial geographies was used as fuel to advance neoconservative spatial and fiscal ideologies in the months and years following Katrina (Peck 2006). Despite the hegemony of racial neoliberalism as the city's redevelopment paradigm, urban planning and numerous participatory processes in the years following Katrina promised possible avenues for eliciting more just visions for the city's future. Yet, when racialized space is so deep, it cannot be simply solved by existing urban planning paradigms (Omi and Winant 2014; Peck and Tickell 2002; Brand 2015).

This latter point is critical because urban planning, despite its normative commitments to social justice, lacks a clear framework for equity in the late twentieth and early twenty-first centuries (Zapata and Bates 2015). The types of policy making and redistribution of power, wealth, and spatial arrangements required to ameliorate a history of inequality experienced by the city's black population raise critical claims for the state and urban planning policy makers in the neoliberal era (Reardon et al. 2009). There are, to be sure, planners whose work highlights these claims and who work to ameliorate intersecting conditions of racialized/spatialized inequality. Even if urban planning re-embraced policies oriented toward equity and redistribution, as many planners and policy makers did in the 1970s and 1980s (Krumholz 2003), market-based hegemony makes these types of claims less tenable. In this sense, we must understand New Orleans's racial geographies as both evidence of the ongoing work of a racial state and racial formation and also as geographies resynthesized under the guise of neoliberal space-making (Omi and Winant 2014).

Racial geographies are reworked in the neoliberal era, but they are not new. The not-newness of racial geographies underlines the hegemony of a racial state whose development and planning has always been enacted through space. Although many scholars point to this "fatal coupling" (Gilmore 2002) of race and space, the central development dilemma posed by racial geographies is not only that they are not new but that they are normalized in moments such as Katrina and alternatives proposed by black residents have been largely muted under neoliberal colorblindness (Reardon et al. 2009.) Yet, the effects of political economies and racial landscapes 
cannot be extracted from the development modalities that produced the pre-Katrina moment and the deep environmental injustices that existed prior to the storm. The environmental and development landscape underlies how racial justice was spatialized and it is to this development dilemma that we now turn.

\subsection{Unjust and Unequal Environmental Development}

New Orleans is an "impossible but inevitable city" (Lewis 2003, p. 19) born of the logics of economic expansion and the management of nature, both of which coincide with a racialized development history. The city is located on an unstable deltaic plain that features the dangerous convergence of sea-level rise and shrinkage of the land (subsidence). This convergence is made more dangerous by reduced rates of sediment supply to rebuild land due to the construction of an extensive levee and canal system to protect the city from flooding (Blum and Roberts 2012). Put another way, construction of levees and drainage canals increases subsidence and flood risk and therefore contains an environmental contradiction because they dry out land and reduce the ability of the Mississippi River to deposit sediment required to make new land (Baxter 2014). Consequently, further drowning of land in the deltaic plain of New Orleans is inevitable, which means every citizen of New Orleans is at considerable risk of future flooding (Blum and Roberts 2012).

Not every citizen of New Orleans confronts an equal risk of exposure to future flooding because of the city's history of unequal and uneven development. Structural patterns of inequality and racism created and sustained unequal power relations and increased disaster vulnerability for poor black citizens shunted into more floodprone parts of the city; this is a condition that has not abated post-Katrina (Susman et al. 1983; Freudenberg et al. 2008).

\subsubsection{A History of Environmental Vulnerability in New Orleans}

New Orleans is a flood-prone city where, after the demise of slavery, blacks, indigenous peoples, criminals, and outcasts largely populated marginal lands with inferior drainage near industrial areas and in back swamps located beyond the thin teapot or, "sliver by the river," that lies above sea level (Lewis 2003; see Fig. 8.1). It is well documented how the city expanded toward Lake Pontchartrain when invention of the wood screw pump enabled drainage of former back swamps (Lewis 2003; Colten 2005; Campanella 2008). Subdivisions sprang up across the center and back of town, some of which carried racial covenants to keep out blacks and other so-called undesirables. The city became reliant on pumping floodwaters out of these flood-prone areas whenever there was a hard rain. However, pumping stations 
and drainage canals were not enough to protect the city from storm surge associated with a major hurricane. That required federal intervention.

Congress authorized federal involvement in levee protection for New Orleans in 1955 when it ordered the Army Corps of Engineers to develop plans for a Lake Pontchartrain and Vicinity Hurricane Protection Project. Substantial funding for the project became available in 1965 when Congress allocated \$56 million for hurricane protection in New Orleans after Hurricane Betsy flooded 6600 homes, many in eastern New Orleans (Seed and Bea 2006, p. 4-22; Shallat 2006). Political wrangling continued for decades between real estate investors, environmental activists, and other community groups, over the extent and type of levee protection to construct. A "high-level" barrier plan that required raising, strengthening, and extending existing levees was finally adopted in 1985 and produced the hurricane protection system that failed catastrophically when Hurricane Katrina struck the city (Seed and Bea 2006).

Construction of a hurricane protection system for New Orleans suffered with the roll out of the neoliberal policy regime in the 1980s. Sporadic funding and costcutting private contractors delayed completion of the levee system as corners were cut on site preparation and building materials, especially on levees built along major outfall canals that drain water out of the city and along the Industrial Canal (Seed and Bea 2006). The mark of neoliberalism was also evident in rollbacks of environmental regulations after the election in 1980 of President Ronald Reagan consolidated government power in favor of financial and land-use deregulation to stimulate real estate investment as a cornerstone of national economic policy (Hackworth 2007). Federal agencies like the Federal Emergency Management Administration (FEMA) and the National Flood Insurance Program provided insurance that softened oversight of local land-use policies and increased federal responsibility for flood risk, which empowered real estate developers and resulted in a 50 percent increase over 30 years in floodplain construction across the country (Burby 2001). New Orleans was no exception as construction of subdivisions flourished on illprepared swamp land in New Orleans East and on the West Bank of the Mississippi River (Baxter 2014).

Katrina flooded eighty percent of New Orleans and the damage raged across social class and racial lines, though low-income black areas were most likely to be damaged by floodwaters (Logan 2006) and black residents were the most impacted. Post-World War II migration of whites to Lakeview, Gentilly, and parts of New Orleans East placed them in slab houses built at grade below sea level, so failure of the Army Corps to construct adequate levees, and inadequate land-use regulations, made these affluent areas vulnerable to extreme flooding as well. While many affluent whites suffered flood damage from Katrina, the white population had had a significant out-migration from New Orleans East before Katrina, thus reducing their vulnerability. White residents also dominated the high ground along the river and the river bend in Algiers, the French Quarter, Bywater, and Marigny neighborhoods that largely escaped the flood as well as the artificial high ground created at the Lake's edge by using lake dredge (see Fig. 8.1). If we recall that many black neighborhoods are located in a belt located off the river (Central City, Mid-City, Gentilly, 
Upper Ninth Ward) that severely flooded, racial inequities in exposure to flooding are clear (Logan 2006).

\subsubsection{Race and Environmental Justice in Post-Katrina New Orleans}

Concerns about environmental justice in post-Katrina New Orleans are multi-scaled and multifaceted. The development dilemma posed by the city's daunting environmental future is twofold. First, the environmental development history of the city created sociospatial vulnerability to large-scale events such as Hurricane Katrina and to everyday flooding events like the rain-event flood in August, 2017, which dumped 8-10 inches of rain on the city within 4 hours. These concerns are not equally dispersed across the city nor are residents equally situated to respond to environmental crises, making non-white and lower-income residents more vulnerable than others. Second, rational responses to recovery that attempted solutions abstracted from larger sociopolitical and racialized contexts largely failed to attend deeper racial and political economies. Not only were residents geographically unequally vulnerable prior to the storm; those vulnerabilities were exacerbated by solutions posed for rebuilding different areas of the city after the storm.

Environmental vulnerability is coupled closely with racialized environmental injustice in New Orleans. Toxic sites such as landfills and industrial plants are more likely sited in the city's black geographies. The Ninth Ward is bisected by the Industrial Canal, constructed in the 1920s to improve shipping along the Gulf Coast. On one side of the Industrial Canal lies the Agriculture Street landfill, a toxic site that festered for decades under the HUD funded Press Park housing development, constructed for low-income blacks in the late 1960s (Webster 2016b). The local school, Moton Elementary, also sat above the landfill, and the former Desire public housing development was not far away. Before the storm, low-income black homeowners on the east side of the Canal in the Lower Ninth Ward were protected by an inferior sheet pile levee built only 3 feet above grade on a small berm of land that was overwhelmed by Katrina's tidal surge (Seed and Bea 2006).

\subsubsection{Post-disaster Redevelopment and Environmental Justice}

Katrina's levee breaks not only devastated tens of thousands of properties; they exposed the city's deep and multi-scaled environmental dilemmas. Despite calls by activists across the city, the massive work required to rebuild levees after Katrina and to analyze the city's environmental vulnerability remains incomplete. The city is reliant on a drainage system with outdated pumping technologies and an unreliable pumping system. It also relies on a levee system and coastal restoration 
programs whose locus of control lies outside the scale of the city, which reveals the multifaceted scales of hurricane protection and seemingly intractable problems associated with land loss and climate change.

A proposal advanced by planners to move entire communities, such as the Lower Ninth Ward, to higher ground through land swap programs designed to keep residents together failed to gain real traction after the storm. What has gained traction are efforts to utilize urban planning to catalyze stormwater management alternatives across the city. This is mainly contained in the city's master plan, comprehensive zoning, and water planning efforts. The Master Plan, completed in 2010, and the Comprehensive Zoning Ordinance, completed in 2015, handle stormwater management by private development incentives. The Water Plan, which the city largely adopted as its resiliency plan, is primarily focused on subsidence and "living with water" via new stormwater management systems, such as bioswales and blueways. As Fisch (2014) shows, the water plan has largely failed to address underlying racial equity concerns and, outside of raising property values in a city already plagued by affordable housing issues, has failed to consider the alignment of stormwater management issues associated with racialized landscapes and a right to place. For instance, one of the proposals in the Water Plan would replace a large swath of the Lowe Ninth Ward with a blue way in an area where some residents have already rebuilt their homes. The failure here is not necessarily in thinking that big changes are necessary for more environmentally just landscapes, but in not recognizing the ways that these landscapes intersect with racial processes and other forms of dispossession that Lower Nine residents have faced.

The city's environmental injustice geography has deepened along racial fault lines since Katrina. For instance, in the wake of the storm, the city pushed to open a new landfill next to the Vietnamese community of Village de l'est in New Orleans East (See Fig. 8.1). In addition, the Army Corps of Engineers renewed planning efforts to redesign the Industrial Canal lock, despite continued opposition from Lower Ninth Ward residents who, citing the repercussions of disrupting toxic canal mud and then dumping newly cut fill into Bayou Bienvenue, continue to fight the lock redesign after decades of doing so.

Environmental injustice concerns connected to the historical development of the city, subsidence, and increased vulnerability to climate change and land loss present an imposing set of physical and environmental dependencies that are difficult to address in a political climate where climate change denial prevails at high levels of government. Centrality of an environmentally just landscape to our thinking about social justice agendas and how to actualize them is also hindered by ongoing racial projects at work in redevelopment that fail to account for the nimble ways racialization is deployed and redeployed spatially. Much like Colten's (2002) analysis of the mutual evolution of racial and geographic landscapes, and Hardy et al.'s (2017) understanding of racial landscapes and vulnerabilities as always in formation, we think of rational approaches to post-Katrina resettlement (e.g., BNOB Commission, Urban Land Institute, Rockefeller-backed resiliency plans) as bound up in contemporary "color blind" racial processes and structures. These rational approaches to green redevelopment largely fail to deal with the political economy of disasters and 
the deeper racial terrain within which new modes of "environmentally just" landscapes are promoted.

Rational policy proposals to focus development on higher ground that is less prone to flooding and extreme environmental events do not actualize racially equal landscapes unless all metrics of access to these high-ground neighborhoods are worked out. It is evident that increased green gentrification along high-ground areas, including rising land values and an increase in green amenities, has reproduced a geography where white and affluent residents are better protected and black residents are more vulnerable (Anguelovski et al. 2018; Brand and Bailey 2017). Without mechanisms that center racial equity and access to affordable housing and community development support, market-led approaches to high-ground resettlement can lead to less affordable housing and increased displacement of economically vulnerable residents (Brand and Bailey 2017).

\subsection{Discussion: Cumulative and Compounding Dilemmas}

It is impossible to extract environmental vulnerability from the larger social systems within which it takes place. As Laska and Morrow (2006, p. 16) argue, social vulnerability "comes not so much from exposure as from the manner in which humanenvironment systems are coupled." More recent work by Hardy et al. (2017, p. 63) argues further that "racial formations are also environmental" and that the "socioecological relations of racialized space" are produced over time through racial projects. What we see in the post-disaster city are a new series of interdependent elements of a twenty-first century racial project built on a veneer of rationality and color-blind decision-making.

Each of the development dilemmas discussed above enables a general perpetuation and intensification of the types of social and environmental injustices prevalent in New Orleans prior to Katrina. The onset of a racial state committed to the reproduction of white privilege after the demise of slavery concocted various strategies to isolate black and other minority residents on lower, less well-drained land in New Orleans. Efforts to remedy racial residential segregation in the late twentieth century largely failed as market-oriented and color-blind spatial logics ostensibly replaced race with wealth and income as criteria to allocate home mortgages and rebuilding funds. Promotion of color-blind, market-oriented governmental interventions, and a slow withdrawal of the state from social services, helps some residents while abandoning others. At the end of the day, life is harder for economically and socially disadvantaged residents that lived in New Orleans prior to the storm and whose efforts to return were often blocked.

Neoliberalism can be examined as racial structuring that reinvigorated and transformed racialized landscapes that existed prior to the storm, but not in ways that attenuate racial injustice. Put simply, poor African-American residents that made up the majority of the city's population before Katrina are faced with daunting obstacles, not only in terms of day-to-day living in an unequal city but also in terms of the 
complex dimensions of resettlement and claims making on the state that could center the reality of racialized politics and contexts of life before and after Katrina. Color-blind racism and individualized solutions to collective problems post-Katrina are further complicated by tensions between the history of environmental development, environmental justice, and future development plans.

We find Colten's (2002) framing of "mutually evolving patterns" useful for thinking about how these dilemmas compound one another. Neoliberalism marked recovery and rebuilding of the city, yet this color-blind approach is itself blind to underlying racial structures. Historically, we see this in Colten's analysis of progressive era approaches to constructing the City's drainage systems where, despite racially progressive development goals to extend drainage to all residents, land reclamation intersected with and created new, racially segregated geographies toward the lake. The rational approach, at the time, extended the geographies of racial residential segregation and uneven development. This pattern repeats post-Katrina, but in particular ways that reproduce a geography of racialized environmental vulnerability in an era of increasing climate change vulnerability. Here, we suggest that whiteness and white supremacist systems are reworked geographically in the postKatrina city along environmental, developmental, and racial fault lines.

Claims for racial justice and equity made by residents in the Lower Ninth Ward and New Orleans East are not easily settled by rational approaches to planning or by decisions about where development should or should not happen. Lower-lying areas such as the East and the Lower Ninth Ward are more vulnerable to flooding, but so too are the Lakeview and Gentilly areas of the city. The point is that the longer history of who settled where reveals more complicated histories that require attention if we are to imagine and promote more socially, racially, economically, and environmentally just landscapes.

\subsection{Conclusion}

This chapter rests within a volume which argues that Louisiana is ahead of the curve regarding what it can teach us about post-disaster redevelopment. New Orleans is 14 years past a devastating human-made catastrophe that brought existential threats to the city. The incredibly hardworking and engaged efforts of residents and supporters, aided by billions in disaster aid and insurance money, rebuilt the city, albeit in ways that largely reinforced preexisting inequities and development dilemmas.

Perhaps, if New Orleans is ahead of the curve, it is in the demonstrative confrontation with and illumination of the types of development dilemmas that we outlined above. Scholarship on neoliberalism, racial geographies, and environmental justice abounds, but at the nexus of the three lie specific entanglements that make dreams of a socially and racially just and resilient city incredibly difficult to realize-if attention to racialized geographic formations and reparations for these formations are not centrally attended to in our future imagining and day-to-day decisions. If New Orleans is ahead of the curve, it is ahead in its illumination of the depth of 
these dilemmas and the ease with which racial inequality is reproduced through disciplines committed to equity.

Despite ominous warnings, we do not wish to squash dreams of a more resilient, green, sustainable, socially just and equal landscape, nor are we convinced of the impossibility of these claims and visions. Lessons learned from rebuilding New Orleans after Katrina contain many seeds for hope. However, what we do suggest is that the paradigms within which we operate matter in terms of shaping disaster response. Further, what post-Katrina development shows is that the moment of Katrina provided an opening through which a highly racialized neoliberalism powerfully framed what happened to the city and what should happen next. The velocity and multidimensionality of this redevelopment trajectory itself poses dilemmas for enacting more racially just landscapes unless these paradigms are called to task.

\section{References}

Akers, J. M. (2012). Separate and unequal: The consumption of public education in post-Katrina New Orleans. International Journal of Urban and Regional Research, 36(1), 29-48. https:// doi.org/10.1111/j.1468-2427.2011.01062.x.

Anguelovski, I., Connolly, J., \& Brand, A. L. (2018). From landscapes of utopia to the margins of the green urban life: For whom is the new green city? City, 22(3). https://doi.org/10.1080/136 04813.2018.1473126.

Arena, J. (2012). Driven from New Orleans: How nonprofits betray public housing and promote privatization. Minneapolis, MN: University of Minnesota Press.

Baptist, E. E. (2014). The half has never been told: Slavery and the making of American capitalism. New York, NY: Basic.

Barrios, R. E. (2010). You found us doing this, this is our way: Criminalizing second lines, Super Sunday, and habitus in post-Katrina New Orleans. Identities: Global Studies in Culture \& Power, 17(6), 586-610.

Bates, L. K., Towne, S. A., Jordan, C. P., \& Lelliott, K. L. (2018). Introduction: What shakes loose when we imaging otherwise. Planning Theory \& Practice, 19(2), 254-256. https://doi.org/10. 1080/14649357.2018.1456816.

Baxter, V. (2014). Rent, real estate, and flood mitigation in New Orleans East. Antipode, 46(4), 1014-1031. https://doi.org/10.1111/anti.12080.

Baxter, V., \& Casati, M. (2019). Building black suburbs in New Orleans. In T. Adams \& M. Sakakeeny (Eds.), Remaking New Orleans: Beyond Exceptionalism \& Authenticity (pp. 203-233). Durham, NC: Duke University Press.

Blum, M. O., \& Roberts, H. (2012). The Mississippi Delta region: Past, present, and future. Annual Review of Earth \& Planetary Sciences, 40, 655-683. https://doi.org/10.1146/ annurev-earth-042711-105248.

Brand, A. L. (2007). Rebuilding the right to return: Toward a framework of social and spatial justice in New Orleans. Critical Planning, 14, 71-89.

Brand, A. L. (2015). The politics of defining and building equity in the 21st century. Journal of Planning Education \& Research, 35(3), 249-264. https://doi.org/10.1177/0739456X15585001.

Brand, A. L. (2018). The duality of space: The built world of Du Bois' doubleconsciousness. Environment and Planning D: Society and Space, 36(1), 3-22. https://doi. org/10.1177/0263775817738782.

Brand, A. L., \& Bailey, H. (2017, April). High ground, low ground: The new topography of racial development in the 21st century. Presentation at the annual meeting of Association of American Geographers Conference, Boston, MA. 
Brenner, N., \& Theodore, N. (2002). Cities and the geographies of actually existing neoliberalism. Antipode, 34(3), 349-379. https://doi.org/10.1111/1467-8330.00246.

Bring New Orleans Back Commission (BNOB). (2006). Action Plan for New Orleans: The New American City. BNOB Urban Planning Committee. New Orleans, LA: BNOB Commission.

Brown, E. (2015, September 3). Katrina swept away New Orleans' school system, ushering in new era. Washington Post. Retrieved from https://www.washingtonpost.com/news/ education/wp/2015/09/03/katrina-swept-away-neworleans-school-system-ushering-in-new era/?noredirect=on\&utm_term $=.6 \mathrm{c} 3 \mathrm{e} 8 \mathrm{beb} 9857$

Burby, R. J. (2001). Flood insurance and floodplain management: The U.S. experience. Journal of Environmental Hazards, 3(3), 111-128. https://doi.org/10.1016/S1464-2867(02)00003-7.

Burley, D. (2010). Losing ground: Identity and land loss in coastal Louisiana. Oxford, MS: University Press of Mississippi.

Campanella, R. (2006). Geographies of New Orleans: Urban fabrics before the storm. Lafayette, LA: University of Louisiana Lafayette.

Campanella, R. (2008). Bienville's dilemma: A historical geography of New Orleans. Lafayette, LA: University of Louisiana Lafayette.

Colten, C. E. (2002). Basin Street blues: Drainage and environmental equity in New Orleans, 1890-1930. Journal of Historical Geography, 28(2), 237-257. https://doi.org/10.1006/ jhge.2001.0400.

Colten, C. E. (2005). An unnatural metropolis. Baton Rouge, LA: Louisiana State University Press.

Crescent Growth Capital Staff. (2018). "Past Projects." Retrieved from www.crescentgrowthcapital.com

Crutcher, M. E., Jr. (2010). Tremé: Race and place in a New Orleans neighborhood (Vol. 5). Athens, GA: University of Georgia Press.

Du Bois, W. E. B. (1962). Black reconstruction in America: Toward a history of the part which black folk played in the attempt to reconstruct democracy in America, 1860-1880. New York, NY: Russell and Russell.

Fisch, J. (2014). Green infrastructure and the sustainability concept: A case study of the Greater New Orleans Urban Water Plan (Master's thesis). University of New Orleans Thesis and Dissertations. 1869.

Freudenberg, W. R., Gramling, R., Laska, S., \& Erikson, K. T. (2008). Organizing hazards, engineering disasters? Improving the recognition of political-economic factors in the creation of disasters. Social Forces, 87(2), 1015-1038. https://www.jstor.org/stable/20430901.

Gilmore, R. W. (2002). Fatal couplings of power and difference: Notes on racism and geography. The Professional Geographer, 54(1), 15-24. https://doi.org/10.1111/0033-0124.00310.

Gotham, K. F. (2007). Authentic New Orleans: Tourism, culture, and race in the Big Easy. New York, NY: New York University Press.

Hackworth, J. (2007). The neoliberal city. Ithaca, NY: Cornell University Press.

HANO. (2019). https://www.hano.org/housing/hcvp.aspx. Accessed August 2019.

Hardy, R. D., Milligan, R. A., \& Heynen, N. (2017). Racial coastal formation: The environmental injustice of colorblind adaptation planning for sea-level rise. Geoforum, 87, 62-72. https://doi. org/10.1016/j.geoforum.2017.10.005.

Harvey, D. (2005). A brief history of neoliberalism. New York, NY: Oxford University Press.

Hastings, D. (2004). Early neighborhood development in New Orleans: Neither new south nor old (Unpublished Dissertation). College of Urban \& Public Affairs, University of New Orleans. New Orleans, LA.

Johnson, C. (Ed.). (2011). The neoliberal deluge: Hurricane Katrina, late capitalism, and the remaking of New Orleans. Minneapolis, MN: University of Minnesota Press.

Johnson, W. (2013). River of dark dreams. Cambridge, MA: Harvard University Press.

Kelley, R. D. G. (2003). Disappearing acts: Capturing Harlem in transition. In Introduction in Alice Attie: Harlem on the verge. New York, NY: Quantuck Lane Press.

Klein, N. (2007). The shock doctrine: The rise of disaster capitalism. New York, NY: Metropolitan Books. 
Krumholz, N. (2003). Equitable approaches to local economic development. In S. S. Fainstein \& S. Campbell (Eds.), Readings in planning theory (pp. 224-236). Malden, MA: Blackwell.

Laska, S., \& Morrow, B. H. (2006). Social vulnerabilities and Hurricane Katrina: An unnatural disaster in New Orleans. Marine Technology Science Journal, 40(4), 15-26. https://doi. org/10.4031/002533206787353123.

Lewis, P. F. (2003). New Orleans: The making of an urban landscape (p. 42). Santa Fe, NM: Center for American Places.

Logan, J. R. (2006). Impact of Katrina: Race and class in storm damaged neighborhoods. Providence, RI: Brown University Publication. Retrieved from https://s4.ad.brown.edu.

Lowe, K., Brand, A. L., \& Hall, E. (2018, October). Off track? The racial dimensions of the modern streetcar. Presentation at the annual meeting of Association of Collegiate Schools of Planning Conference, Buffalo, NY.

McKittrick, K. (2006). Demonic Grounds: Black women and the cartographies of struggle. Minneapolis, MN: University of Minnesota Press.

McKittrick, K., \& Woods, C. (2007). Black geographies and the politics of place. Boston, MA: South End Press.

Morse, R. (2008). Environmental justice through the eye of Hurricane Katrina. Washington, DC: Joint Center for Political and Economic Studies, Health Policy Institute.

Novogradac, M. (2015). Lessons from Katrina include value of tax credit programs. Novogradac. Retrieved from https://www.novoco.com/notes-from-novogradac/lessons-katrina-includevalue-tax-credit-programs

Omi, M., \& Winant, H. (1994). Racial formation in the United States. New York, NY: Routledge.

Omi, M., \& Winant, H. (2014, October 8). How colorblindness co-evolved with free market thinking. The Public Eye. Retrieved from https://www.politicalresearch.org/2014/10/08/ how-colorblindness-co-evolved-with-free-market-thinking/

Ott, K. B. (2012). The closure of New Orleans' Charity Hospital after Hurricane Katrina: A case of disaster capitalism (Unpublished master's thesis). University of New Orleans. New Orleans, LA.

Peck, J. (2006). Liberating the city: Between New York and New Orleans. Urban Geography, 27(8), 681-713. https://doi.org/10.2747/0272-3638.27.8.681.

Peck, J., \& Tickell, A. (2002). Neoliberalizing space. Antipode, 34(3), 380-404. https://doi. org/10.1111/1467-8330.00247.

Plyer, A. (2016, August 26). Facts for features: Katrina Impact. Retrieved from https://www.datacenterresearch.org/data-resources/katrina/facts-for-impact/

Reardon, K. M., Green, R., Bates, L. K., \& Kiely, R. C. (2009). Overcoming the challenges of postdisaster planning in New Orleans: Lessons from the ACORN housing/university collaborative. Journal of Planning Education and Research, 28(3), 391-400. https://doi.org/10.1177/07394 56X08327259.

Reed, A. (2006, September 18). Undone by neoliberalism. The Nation. Retrieved from https:// www.thenation.com/article/undone-neoliberalism/

Seed, R. G., \& Bea, R. B. (2006, May 23). Investigation of the performance of the New Orleans flood protection system in Hurricane Katrina on August 29, 2005 (Report No. UCB-CCRM of the Independent Levee Investigative Team). Berkeley, CA: University of California-Berkeley.

Shallat, T. (2006). Holding Louisiana. Technology \& Culture, 47(1), 102-107. https://www.jstor. org/stable/40061011.

Spain, D. (1979). Race relations and residential segregation in New Orleans: Two centuries of paradox. Annals of American Academy of Political \& Social Science, 441, 82-96. https://www. jstor.org/stable/1043295.

Susman, P., O’Keefe, P., \& Wisner, B. (1983). Global disasters: A radical interpretation. In K. T. Hewitt (Ed.), Interpretations of calamity (pp. 263-283). Boston, MA: Allen-Unwin.

Tulane School of Architecture. (2007, December). The "Big Four" public housing projects are demolished post-Katrina. New Orleans Preservation Timeline Project. Retrieved from https:// www.architecture.tulane.edu 
US American Community Survey. (2016).

US Census. (2000; 2010).

Von Hoffman, A. (2000). A study in contradictions: The origins and legacy of the Housing Act of 1949. Housing Policy Debate, 11(2), 299-325. https://doi.org/10.1080/10511482.2000.95213 70.

Wacquant, L. (2010). Crafting the neoliberal state: Workfare, prisonfare, and social insecurity. Sociological Forum, 25(2), 197-222. https://doi.org/10.1111/j.1573-7861.2010.01173.x.

Weber, R. (2002). Extracting value from the City: neoliberalism and urban redevelopment. Antipode, 34(3), 519-540.

Webster, R. A. (2016a, March 22). New Orleans public housing remade after Katrina. Is it working? Times-Picayune/Nola.com. Retrieved from https://www.nola.com/katrina/index.ssf/2015/08/ new_orleans_public_housing_dem.html

Webster, R. A. (2016b, August 29). The poisoned promises of Agriculture Street. TimesPicayune/Nola.com. Retrieved from https://www.nola.com/politics/index.ssf/2015/04/ agriculture_street_landfill_ne.html

Whitehall, G., \& Johnson, C. (2011). Making citizens in Magnaville: Katrina refugees and neoliberal self-governance. In C. Johnson (Ed.), The neoliberal deluge: Hurricane Katrina, late capitalism, and the remaking of New Orleans (pp. 60-84). Minneapolis, MN: University of Minnesota Press.

Woods, C. (2017). Development drowned and reborn: The blues and bourbon restorations in postKatrina New Orleans (Vol. 35). Athens, GA: University of Georgia Press.

Zapata, M. A., \& Bates, L. K. (2015). Equity planning revisited. Journal of Planning Education and Research, 35(3), 245-248. https://doi.org/10.1177/0739456X15589967.

Open Access This chapter is licensed under the terms of the Creative Commons Attribution 4.0 International License (http://creativecommons.org/licenses/by/4.0/), which permits use, sharing, adaptation, distribution and reproduction in any medium or format, as long as you give appropriate credit to the original author(s) and the source, provide a link to the Creative Commons license and indicate if changes were made.

The images or other third party material in this chapter are included in the chapter's Creative Commons license, unless indicated otherwise in a credit line to the material. If material is not included in the chapter's Creative Commons license and your intended use is not permitted by statutory regulation or exceeds the permitted use, you will need to obtain permission directly from the copyright holder. 